\title{
Four Ponto-Caspian and one American gammarid species (Crustacea, Amphipoda) recently invading Polish waters
}

\author{
Krzysztof Jazdzewski, Alicja Konopacka \& Michal Grabowski \\ Department of Invertebrate Zoology and Hydrobiology, University of Lodz, $12 / 16$ Banacha str., 90237 Lodz, \\ Poland
}

Keywords: Biogeography, gammarids, European waters, Poland

\begin{abstract}
The paper discusses recent drastic changes in the composition of Polish gammarid fauna, that occurred at the end of $20^{\text {th }}$ century. This change was caused by the invasion of five alien species - four of Ponto-Caspian origin (Dikerogammarus haemobaphes, D. villosus, Obesogammarus crassus and Pontogammarus robustoides) and one of American origin (Gammarus tigrinus). Probable invasion routes are presented.
\end{abstract}

\section{Contents}

Abstract

Introduction

Review of recent immigrants

116

The present state of Polish gammarid fauna $\quad$ * 117

Discussion

119

Acknowledgements

121

References

121

\section{Introduction}

Geographical ranges of animals and plants change permanently in time, however these changes, when natural, are slow from the human point of view. Even the geologically young formation of the present North-European fauna, that has begun after the last Würm glaciation and continues till now for some 15 thousands of years, from our perspective is a rather long process. The rapid development of civilisation, and especially of human intercontinental migrations commencing some 5 centuries ago, have accelerated seriously biogeographical changes by intentional acclimatisations, accidental introductions
(Di Castri 1989) and, in the case of freshwater fauna, by the construction of artificial waterways joining formerly separate river systems (Jazdzewski 1980).

Central Europe is drained by the rivers discharging into the North Sea, Baltic Sea and Black Sea. The constructions of man-made canals joining these different basins started in XVIIIth century and during two next centuries these three basins were interconnected in several ways. Major important canals to be mentioned here are those connecting the Elbe and Oder (opened in 1746), the Oder and Vistula (1774) and the Vistula and Dnieper systems (1784, Bug - Pripet' canal) (Jazdzewski 1980).

The area of Poland belongs nearly entirely to the Baltic Sea basin, and some $90 \%$ of this territory belongs to the Oder and Vistula drainage systems. Only the minor part of northern Poland is drained by smaller rivers emptying directly into the Baltic Sea.

Until recently gammarid species were usually recognised as members of the extra-large family Gammaridae. Amphipod genera ascribed to this family sensu Stebbing (1906) appeared to be really not related to each other, however this old familial arrangement, especially of freshwater, Holarctic Amphipoda, persisted very long. Stock $(1968,1974)$, Karaman (1977), Bousfield $(1977,2001)$ and Barnard \& Barnard (1983) made attempts to group the phyletically related "gammarid" taxa using much more detailed morphological analysis.

Starting from the fundamental paper by Sars (1894-1895) the rich, originally Ponto-Caspian amphipod fauna was usually considered to form a part of the family Gammaridae sensu lato (i.a. Carausu 
et al. 1955, Birshtejn \& Romanova 1968, Mordukhaj-Boltovskoj et al. 1969), although already Martynov (1924) commented some special morphological features of many "gammarids" of the so called Ponto-Caspian complex - the features that he has named "pontogammarisation". Stock (1974) has distinguished a group named "Dikerogammarus-Pontogammarus complex" encompassing such genera as Dikerogammarus, Pontogammarus, Stenogammarus, Niphargoides and several others as well as a newly erected Obesogammarus. This group was formally named "family Pontogammaridae" by Bousfield (1977) who has distinguished tentatively 10 family-groups or families (i.a. Gammaridae, Pontogammaridae, Anisogammaridae etc.) forming together the superfamily Gammaroidea. Barnard \& Barnard (1983) have put Gammarus-like genera in the "Gammaroid-group" (that could be possibly situated at the supra-familial level); in this group these authors formally distinguished family Gammaridae with genus Gammarus and several Caspian and Baikalian genera, and 13 groups, possibly of familial level with such master genera as Echinogammarus, Dikerogammarus and Pontogammarus, among others. Until any solid cladistic analysìs of all "gammarid" genera is done, we follow the Bousfield's $(1977,2001)$ classification of Ponto-Caspian gammarids in the family Pontogammaridae, leaving the genera Gammarus, Echinogammarus and Chaetogammarus in the family Gammaridae s.str., and retaining the widely used vernacular name "gammarid" for both the superfamily Gammaroidea sensu Bousfield (1977) and a "Gammaroid-group" sensu Barnard \& Barnard (1983).

Our department has studied for several decade the gammarid fauna of Poland. We have collected and determined altogether some 60,000 individuals in about 1200 samples taken in the whole country. The data obtained till 1990 were summarised in two monographs by Jazdzewski (1975) and Jazdzewski \& Konopacka (1995). At that time Polish gammarid fauna encompassed 15 gammarid species.

Results of our recent studies (1997-2001), focusing on large rivers (more than 100 samples collected, altogether around 3000 specimens), together with the results obtained by Gruszka (1995, 1999, 2001) in the Oder estuary, allowed to enrich the list of Polish gammarids with 5 alien species, and to recognise their most probable invasion routes.

\section{Review of recent immigrants}

Dikerogammarus haemobaphes (Eichwald, 1841) For the first time in the Baltic Sea basin, the species was recorded in Poland in 1997 (Konopacka 1998). The range expansion of this Ponto-Caspian invader in European waters and in Poland was already presented by Jazdzewski \& Konopacka (2000). Recently, we discovered large population of $D$. haemobaphes in the Vistula Lagoon, Gruszka (2000) and Müller et al. (2001) found this species in the lower Oder river.

\section{Dikerogammarus villosus (Sowinsky, 1894)}

The species was recently recorded in the Oder river, in 1999 (Gruszka 2001, Müller et al. 2001, Jazdzewski and Konopacka 2002) downstream of the canal connecting the Oder river with the Elbe basin. The penetration of $D$. villosus into the Oder basin is especially interesting since it has used first the so-called southern corridor, i.e. Danube river, for westward range expansion (Bij de Vaate et al, 2002). In the upper reach of Danube river $D$. villosus was first recorded by Tittizer et al. (1994) in 1992, and soon it has penetrated into the Rhine river via the Main - Danube canal (Bij de Vaate \& Klink 1995). From the Rhine river D. villosus continued range expansion eastward by using the Mittellandcanal joining the Rhine, Weser, Elbe and Oder basins (Grabow et al. 1998, Zettler 1998, Rudolph 2000). In the lower Oder river, the species co-occurrs with other alien gammarids, like $D$. haemobaphes, $P$. robustoides and G. tigrinus (Müller et al. 2001, own unpubl, data).

Pontogammarus robustoides (G.O. Sars, 1894)

First records of $P$. robustoides come from northwestern Poland. Gruszka (1999) found this species in the Szczecin Lagoon and the lower Oder river in 1988. The species was also reported from the lower Vistula river (Konopacka 1998) and from the Vistula Lagoon (Jazdzewski \& Konopacka 2000). Pontogammarus robustoides reached the Vistula and Oder deltaic systems possibly with ballast waters via 
Baltic Sea from the Neman river system and Curonian Lagoon, where it was introduced in the $1960 \mathrm{~s}$ (Gasjunas 1972, Arbaciauskas, 2002). However, the species could also have entered the Vistula Lagoon through the Pregola river system connecting the Vistula river delta with the Curonian Lagoon. More details on the origins and distribution routes of the mentioned species in Europe can be found in Jazdzewski \& Konopacka (2000).

\section{Obesogammarus crassus (G.O. Sars, 1894)}

This species is most recently discovered in Polish waters, namely in the Vistula Lagoon and in the Dead Vistula in 1998 (Konopacka \& Jazdzewski, 2002). Original distribution areas of $O$. crassus encompassed offshore Caspian Sea waters and lower courses of rivers emptying to this water body; in the Volga river the species penetrated upstream as far as to Volgograd (Mordukhaj-Boltovskoj 1979). In the Black Sea system $O$. crassus occurred originally in brackish lagoons and in the lower courses of large rivers (Dedju 1980, Jazdzewski 1980). In the Danube river it was noted as far upstream, as in its Yugoslavian sector (Dudich 1967). Like $P$. robustoides, $O$. crassus was transplanted in early 1960s into the Kaunas artificial reservoir on the Neman river in Lithuania and from there, after acclimatisation, it entered the Curonian Lagoon (Gasjunas 1972, Arbaciauskas, 2002). Subsequently it entered the Vistula Lagoon, most probably via the Pregel river system. However, due to its comparatively high euryhalinity, $O$. crassus could have also dispersed south-westwards along the Baltic Sea shores, with the average salinity of 7 PSU in this region.

\section{Gammarus tigrinus Sexton, 1939}

This North American euryhaline species was observed in waters with salinities ranging from 1 to 25 PSU (Bousfield 1973). Information on its introduction and distribution routes in Europe have been summarised by Jazdzewski \& Konopacka (2000). First observations of G. tigrinus in Polish waters were done in 1988 in the Szczecin Lagoon (Gruszka 1995, 1999, Wawrzyniak-Wydrowska \& Gruszka 2001). Recent survey of the entire Oder river (unpublished data) proved that $G$. tigrinus entered this river upstream as far as to the city of Opole. The localities of the species in the Vistula Lagoon are by now the easternmost ones in Europe.

\section{The present state of Polish gammarid fauna}

The gammarid fauna of Poland is comparatively well known (Jazdzewski \& Konopacka 1995, Gruszka 1995, 1999, Konopacka 1998, Konopacka \& Jazdzewski 2002). Native freshwater taxa are Gammarus pulex, G. fossarum, G. lacustris, G. varsoviensis, G. leopoliensis and G. balcanicus, whereas the Baltic autochthonous species are $G$. zaddachi, G. salinus, G. duebeni, G. locusta, G. inaequicauda, G. oceanicus and Chaetogammarus stoerensis. Gammarus roeselii was recognized by Jazdzewski \& Roux (1988) as a species of Balkan origin, possibly recently (in XIX century?) entering western and northern Europe via the Danube system. It has possibly used the Danube-Rhein canal and Mittelland-canal in its westward and then eastward range expansion. Until recently the only evidently alien gammarid species was Chaetogammarus ischnus, discovered in the Vistula river in 1928 (Jarocki \& Demianowicz 1931). This species has surely used the Bug-Prypet" canal for range extension from the Dnieper system westward. In the last decades we face an increasing number of invasions of new alien species in Polish waters (Fig. 1). In quite a short time Polish gammarid fauna has been enriched by 5 species: four of Ponto-Caspian origin (Dikerogammarus haemobaphes, D. villosus, Pontogammarus robustoides and Obesogammarus crassus) and one from North America (Gammarus tigrinus). Two of these immigrants, G. tigrinus and $D$. haemobaphes, dominate now the gammarid fauna of lotic environments in the Oder and Vistula rivers, respectively. In the Oder river G. tigrinus is the most common and widespread species, entering upstream as far as nearly to the city of Opole, being the only gammarid species there. In the lower Oder river, especially downstream of its connection with Spree - Havel system and of the Warta river mouth, Dikerogammarus haemobaphes joins G. tigrinus, and, according to Müller et al. (2001) could be even a dominant gammarid in mixed populations. On the other hand $D$. haemobaphes has conquered nearly the entire Vistula river, occurring 


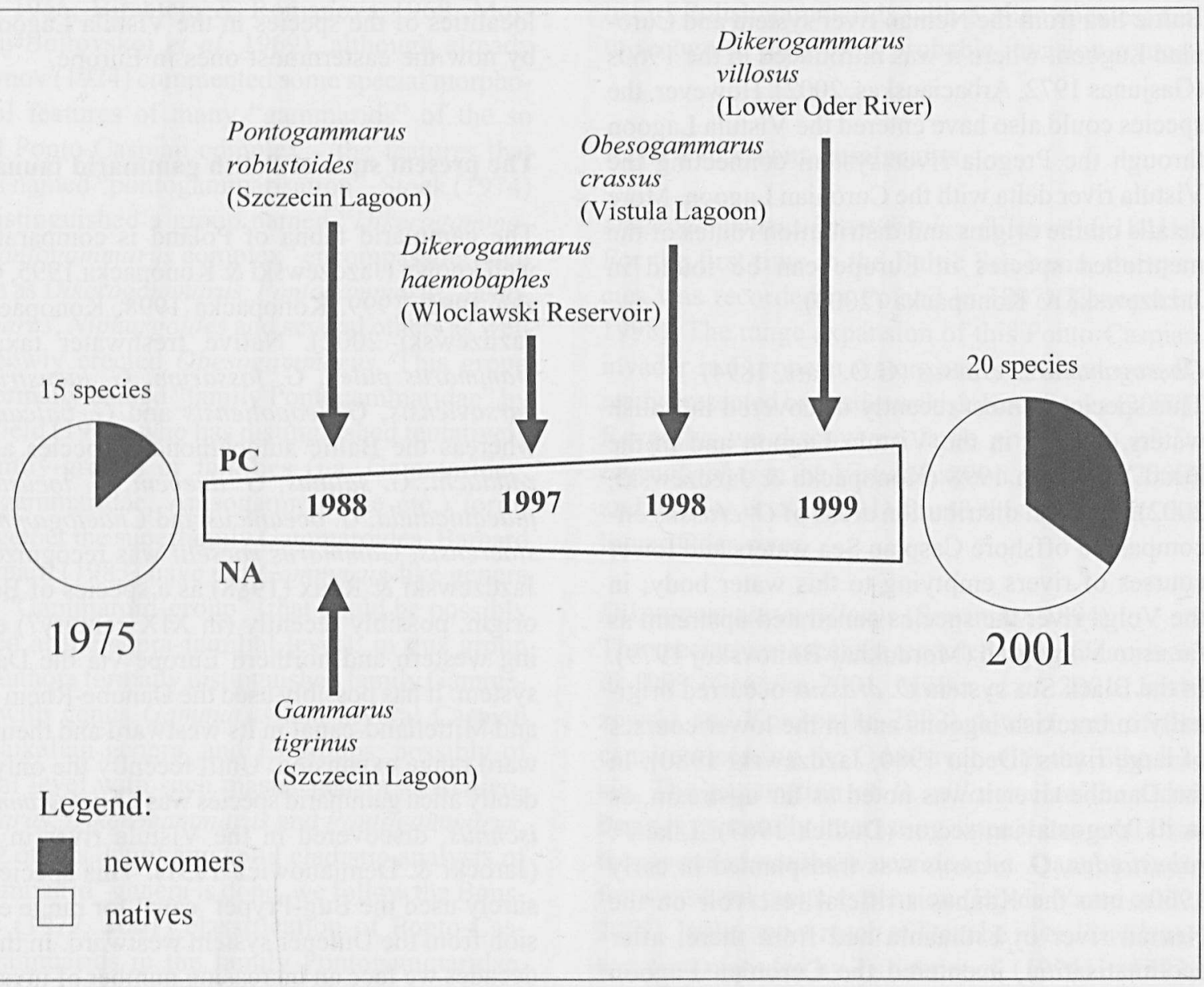

Fig. 1. Changes in gammarid fauna of Polish waters. Place of first record indicated in brackets. PC - Ponto-Caspian species. NA North American species.

usually as an only gammarid species as far upstream as about $100 \mathrm{~km}$ below Cracow. In the lentic conditions of the artificial Wloclawek reservoir in the middle/lower Vistula section, D. haemobaphes was outcompeted by Pontogammarus robustoides. Downstream of this reservoir the more rheophilous $D$. haemobaphes regained its dominance.

Populations of native gammarid species - Gammarus pulex, G. fossarum, G. varsoviensis, and the earlier immigrant $G$. roeselii - were only recorded in some tributaries.

In the $\beta$-oligohaline waters of the Szczecin Lagoon two alien species dominated the gammarid fauna-G. tigrinus and $P$. robustoides (WawrzyniakWydrowska \& Gruszka 2001). In the mostly $\alpha$ oligohaline Vistula Lagoon, in its southern part, the gammarid fauna was dominated by either Obesogammarus crassus and $G$. tigrinus or $P$. robustoides and $O$. crassus. In both cases a small admixture of Gammarus duebeni occurred. D. haemobaphes also occurred in numbers in the less saline $(\beta-$ oligohaline) part of the Lagoon influenced by the Nogat arm of the Vistula. The gammarids occurring along the northern shores of the Vistula Lagoon were mostly dominated by $G$. duebeni or by G. tigrinus, other species found were P. robustoides, Gammarus zaddach $i$ and $O$. crassus. In brackish water of the former Vistula section, called the Dead Vistula (salinity 2-7 PSU) the most common and usually dominant gammarid is $G$. tigrinus, most often accompanied by $G$. zaddachi, sometimes by $D$. haemobaphes and rarely by $G$. duebeni, which was, however, 
the dominant species at the least saline station near the dam separating Dead Vistula from the Vistula river. It is worth while to note, that these same brackishwater bodies - Vistula Lagoon and Dead Vistula - at least till the 1970 s, were mainly inhabited by $G$. zaddachi and $G$. duebeni with varying dominance of one or another species and a very rare presence of Gammarus salinus and G. oceanicus at the entrance of Dead Vistula to the Baltic Sea (Zmudzinski 1957, Arndt 1965, Jazdzewski 1975, and unpubl. observations).

\section{Discussion}

There are several possibilities for gammarid species to extend their original distribution areas. Quite natural way is their upstream migration, especially in large rivers. Segerstrale (1954) suggested that, at least in the case of Gammarus lacustris, the transport by birds could be responsible for the wide distribution of this species in Holarctic. However, in most of the cases discussed we have to do with various kinds of human impact. The construction of canals connecting different drainage areas is one of fundamental reasons of the penetration of particular species into sometimes distant regions. Another factor, often connected with the former one, are intentional introductions of species aimed at the enrichment of fish food resources (Karpevich 1975, Arbaciauskas 2002). In Europe the impact of these both factors upon the range extensions of various amphipod species were amply discussed by Jazdzewski (1980) and, more recently, various alien freshwater invertebrates penetration in western Europe as well as the ecological impact of these invaders were summarised, i.a., by Kinzelbach (1995), Tittizer (1996), Jazdzewski \& Konopacka (2000), Van der Velde et al. (2000), Tittizer et al. (2000) and Bij de Vaate et al. (2002).

One should consider of course, also the possibility of introductions of alien gammarids, for instance by the transfer of aquatic plants; such possibility was suggested for Gammarus roeselii by Jazdzewski \& Roux (1988).

The ballast water transport also cannot be excluded as a factor accelerating gammarid range extensions and, in the case of transatlantic inva- sions of freshwater or oligohaline species (e.g. the case of Chaetogammarus ischnus, Witt et al. 1997) such transport seems to be the major possibility.

However, in European waters, after breaking physical barriers, migrations through canals and along the brackish Baltic Sea littoral waters were the most important way of range extensions. This semi-natural penetration can occur within the same or adjacent biogeographical province of identical or similar climatic conditions.

Recent invasion routes of alien gammarid species in Polish waters are illustrated by Fig. 2. This scheme is based upon the distribution of new and old records of alien gammarids along the Polish river courses given in detail by Jazdzewski \& Konopacka (2002).

The invasion of many Ponto-Caspian species in European freshwaters, and, via freshwaters, into brackish coastal waters of the Baltic and North Seas, is related to their typically oligohaline preferences and relatively high euryhalinity. Most of these species originally live in estuaries and lagoons of the Black and Azov Seas of a low salinity (0.1-7 PSU but mostly 0,5-5 PSU (Mordukhaj-Boltovskoj et al. 1969, Dedju 1980)) as a relict fauna of the Sarmatian or Pontian Age.

The endemic Ponto-Caspian crustacean fauna is probably of a freshwater origin; at present various species exhibit various grades of euryhalinity. In the Caspian Sea itself over 70 endemic malacostracan species were recorded, of them some 15 species (mostly amphipods) penetrated in different distances upstream the Volga river-those being the most euryhaline taxa (Mordukhaj-Boltovskoj \& Dzjuban 1976).

Gammarid species of the so-called Ponto-Caspian complex (see Mordukhaj-Boltovskoj 1964) in general do not occur in the open (central) Baltic Sea of the surface salinity 7-8 PSU, or at least do not compete with native fauna. On the other hand such species, like Chaetogammarus ischnus, Pontogammarus robustoides, Dikerogammarus haemobaphes, $D$. villosus and Obesogammarus crassus are found only in freshwaters or in oligohaline lagoons like Vistula Lagoon (salinity 2-5 PSU) or Szczecin Lagoon (0,5-1,5 PSU) and only there they really may compete with success with native fauna; the same is true for Curonian Lagoon, possibly for 


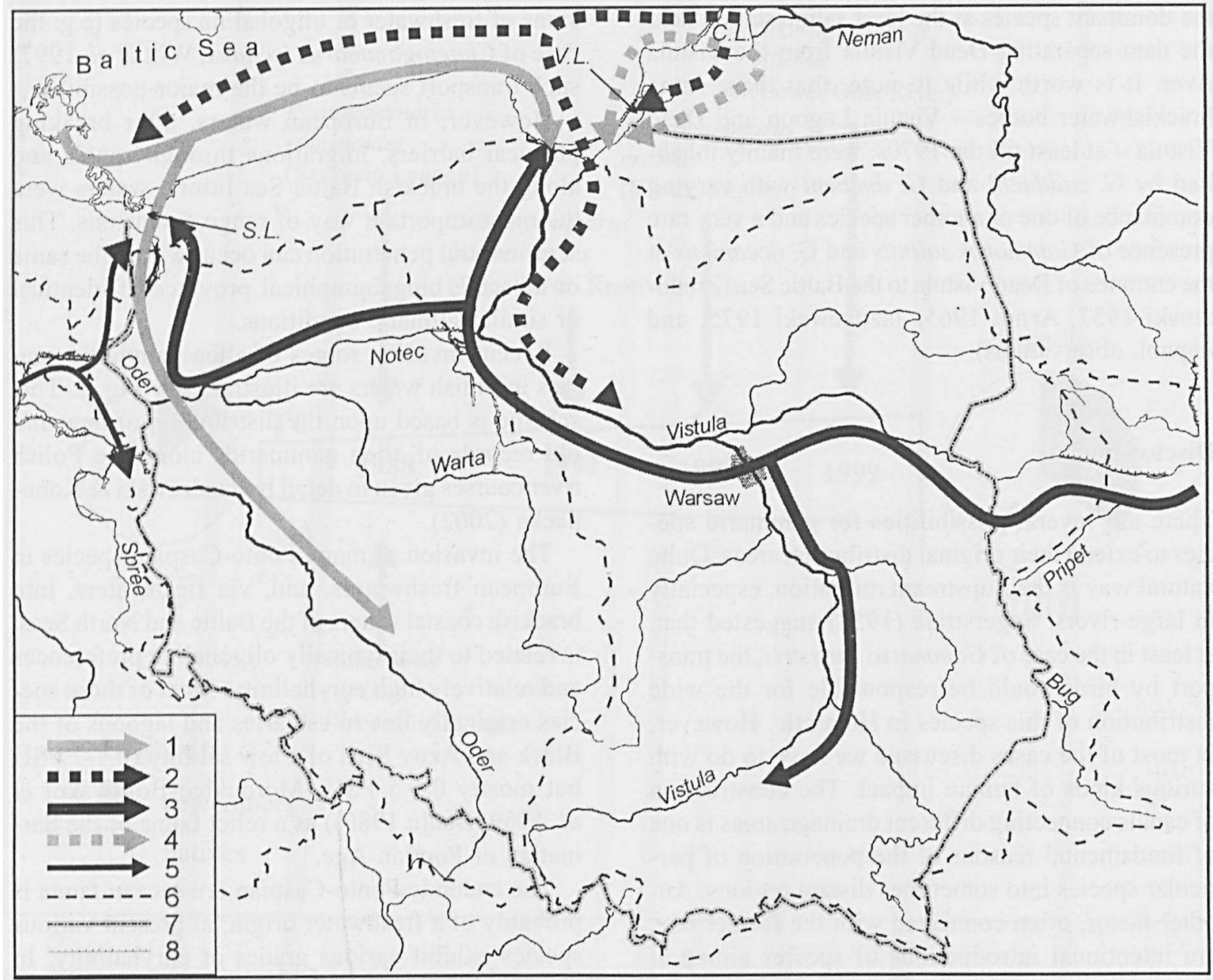

Fig. 2. Immigration routes of invasive gammarid species in Polish waters. 1 - Gammarus tigrinus, 2 - Pontogammarus robustoides, 3 - Dikerogammarus haemobaphes (and Chaetogammarus ischnus, except upstream of Warsaw), 4 - Obesogammarus crassus, 5 - D. villosus, 6 - basin boundaries, 7 - country borders, 8 - artificial waterways, V.L. - Vistula Lagoon, S.L. - Szczecin Lagoon, C.L. - Curonian Lagoon.

Gulf of Riga and Gulf of Finland.

Similar oligohaline preferences of Gammarus tigrinus have been mentioned several times in the literature (Bulnheim 1976, Pinkster et al. 1992).

Although the first record of the invading species may be somewhat delayed and the really first occurrence of a taxon in new place surely precedes this first record, one can assume that this delay is not longer than, say, 3-5 years, taking into account still more and more detailed monitoring of European rivers.

An interesting question arises - why we do observe this rather recent massive invasions of various Ponto-Caspian species in central and western
Europe? (Jazdzewski \& Konopacka 2000, Tittizer et al. 2000, Bij de Vaate et al. 2002, and unpubl. 2000/2001 observations). In Poland one of the reasons can be the increasing ionic content of large rivers in last decades, caused by the industrial pollution (Dojlido \& Woyciechowska 1985, Szymanska 1990, Ficek \& Ficek 1994). This rise in the „salinity" of such rivers like Vistula and Oder would finally reach the „critical point” allowing several species of oligohaline preferences to start their rather quick conquest of new basins. Obviously the increasing transport is also responsible, but when looking for a "trigger" of these invasions and attaining rich populations in the whole river flows in 
comparatively short period the present authors would rather favor the above mentioned hypothesis.

Serious studies on the ecological impact of alien species upon the native fauna in the Vistula and Oder systems are still not undertaken. Quantitative studies on the fish and invertebrates diet are urgently needed to estimate this impact. The present paper shows merely the qualitative aspect of these invasions indicating their possible routes and actual faunistic changes.

\section{Acknowledgements}

Thanks are due to Ewa Janowska, M.Sc. for her generous, active help in collecting and sorting the material, as well as to Przemyslaw Mlynarczyk, M.Sc. and Wlodzimierz Grochala who have been helpful in field investigations. Dr. Abraham Bij de Vaate and the second unknown referee greatly contributed with their opinions to the quality of the present paper.

\section{References}

Arbaciauskas K. 2002. Ponto Caspian amphipods and mysids in the inland waters of Lithuania: history of introduction, current distribution and relations with native malacostracans. In: Leppäkoski E, Olenin S, Gollasch S, eds, Invasive Aquatic Species of Europe. Kluwer Acad. Publ, Dordrecht, Boston, London: 104-115.

Arndt EA. 1965. Û̉ber die Fauna des sekundẫren Hartbodens der Martwa Wisla und ihre Mündungsgebietes (Danziger Bucht). Wiss. Z. Univ. Rostock 14: 645-653.

Barnard JL, Barnard CM. 1983. Freshwater Amphipoda of the world. - Hayfield Association, Mt. Vernon, Virginia, 2 vols.: 830 pp.

Bij de Vaate A, Jazdzewski K, Ketelaars H, Gollasch S, Van der Velde G. 2002. Geographical patterns in range extension of macroinvertebrate Ponto-Caspian species in Europe. Can. J. Fish. Aquat. Sci. 59: 1159-1174.

Bij de Vaate A, Klink AG. 1995. Dikerogammarus villosus Sovinsky (Crustacea: Gammaridae) a new immigrant in the Dutch part of the lower Rhine. Lauterbornia 20:51-54.

Birshtejn JA, Romanova NN. 1968. Otrjad bokoplavy. Amphipoda. In: Birhstejn JA et al.s. eds. Atlas bespozvonochnykh Kaspijskogo morja. Izd, "Pishchevaja Promyslennost", Moskva: 241-289.

Bousfield EL. 1973. Shallow-water Gammaridean Amphipoda of New England. Cornell University Press, Ithaca: 1-312.

Bousfield EL. 1977. A New Look at the Systematics of Gammaridean Amphipods of the World. Crustaceana, Stippl. 4: 282-316.

Bousfield EL. 2001. An updated commentary on phyletic classification of the amphipod Crustacea and its applicability to the North American fauna. Amphipacifica 3: 49-113.
Bulnheim H-P. 1976. Gammarus tigrinus, ein neues raunen-

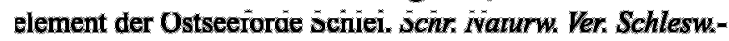
Holst. 46: 79-84.

Carausu S, Dobreanu E, Manolache C. 1955. Amphipoda forme salmastre si de apa dulce. Fauna Rep. popul. Romine, Crustacea 4: 1-409.

Dedju II. 1980. Amfipody presnykh $i$ solonovatykh vod jugozapada SSSR. Izd. "Shtïnca", Kishinev: 223 pp.

Di Castri F. 1989. History of Biological Invasions with Special Emphasis on the Old World. In: Drake JA, Mooney HA, di Castri F, Groves RH, Krüger FJ, Rejmanek M, Williamson M, eds. Biological Invasions, A Global Perspective, Scope 37. John Wiley \& Sons, Chỉchester, New York, Brisbane, Toronto, Singapore: 1-30.

Dojlido JK, Woyciechowska J. 1985. Zmiany jakosei wod powierzchniowych w Polsce w ciagu ostatniego pol wieku. Gospodarka wodna 1-2: 39-44.

Dudich E. 1967. Systematisches Verzeichnis der Tierwelt der Donau mit einer zusammenfassenden Erlaueuterung. Limnologie der Donau, 3: 4-69.

Ficek M, Ficek M. 1994. Czy zdolamy odsolic Wisle? Aura 10 13-14

Gasjunas II. 1972. Obogashchenie kormovoj bazy ryb vodoemov Litvy akklimatizirovannymi rakoobraznymi Kaspijskogo kompleksa. In: Virbickas J, ed. Voprosy razvedenija ryb i rakoobraznykh v vodoemakh Litvy. Vilnius: 57-68.

Grabow K, Eggers TO, Martens A. 1998. Dikerogammarus villosus Sowinsky (Crustacea: Amphipoda) in norddeutschen Kanälen und Flüssen. Lauterbornia 33; 103-107.

Gruszka P. 1995. Gammarus tigrinus Sexton, 1939 (Crustacea: Amphipoda) - nowy dla fauny Polski gatunek w estuarium Odry. In: I Konf. Przyrodnicze aspekty badania wod estuarium Odry $i$ wod jeziornych wojewodztwa szczecinskiego. Mat. Konf. No. 7, Uniw. Szczecin: p. 44.

Gruszka P. 1999. The The River Odra Estuary as a Gateway for Alien Species Immigration to the Baltic Sea Basin. Acta hydrochim. hydrobiol. 27: 374-382.

Gruszka P. 2000. Dikerogammarus haemobaphes (Eichwald, 1841) (Crustacea: Amphipoda) - nowy gatunek w rzece Odrze. Mat. Zjazdowe: XVIII Zjazd Hydrobiologow Polskich, Bialystok: p. 87.

Gruszka P. 2001. Atyaephyra desmaresti (Millet, 1831) (Crustacea: Decapoda) nowy dla fauny Polski gatunek w rzece Odrze. In: Sesja Naukowa z okazji jubileuszu 50-lecia Wydzialu Rybactwa Morskiego i Technologii Zywnosci, Szczecin, 28-29 czerwiec, 2001, Akademía Rolnicza w Szczecinie: p. 31.

Jarocki J, Demianowicz A. 1931. Über das Vorkommen des ponto-kaspischen Amphipoden Chaetogammarus tenellus (G.O. Sars) in der Wisla (Weichsel), Bull. Int. Acad. Pol., Cl. Math. Nat. B (II): 513-530.

Jazdzewskí K. 1975. Morfologia, taksonomia î wystepowanie w Polsce kielzy z rodzajow Gammarus Fabr. i Chaetogammarus Mart. (Crustacea, Amphìpoda), Acta Univ. Lodz., Lodz: 185 pp.

Jazdzewskĩ K. 1980. Range extensions of some gammaridean species in European Inland waters caused by human activity. Crustaceana, Suppl. 6: 84-107. 
Jazdzcwski K, Konopacka A. 1995. Pancerzowce - Malacostraca (procz Oniscoidea). Katalog Fauny Polski, Vol. XIII, I: 165 pp.

Jazdzewski K, Konopacka A. 2000. Immigration history and present distribution of alien crustaceans in Polish waters. In: von Vaupel Klein JC, Schram FR, eds. The biodiversity crisis and Crustacea. Proc. $4^{\text {th }}$ Intern. Crustacean Congress, vol. 2. Brill, Leiden. Crustacean Issues 12: 55-64.

Jazdzewski K, Konopacka A. 2002. Invasive Ponto-Caspian species in waters of the Vistula and Oder basins and of the southern Baltic Sea. Inx Leppakoski E, Olenin S, Gollasch S, eds. Invasive Aquatic Species of Europe. Kluwer Acad. Publ, Dordrecht, Boston, London: 384-398.

Jazdzewski K, Roux AL. 1988. Biogéographìe de Gammarus roeselii Gervais en Europe, en particulier répartition en France et en Pologne. Crustaceana, Suppl. 13: 272-277.

Karaman G. 1977. 68. Contribution to the knowledge of the Amphipoda. Revision of the Echinogammarus genera-complex (fam. Gammaridae). Arh. Biol. Nauka, Beograd 27 (1975): 69-93.

Karpevich AF. 1975. Teorija i praknka akklimatizaciì vodnykh organizmov Izd. "Pishchevaja Promyslennost", Moskva: 1432.

Kinzelbach R. 1995. Neozoans in European waters. Exemplifying the worldwide process of invasion and species mixing. Experientia 51: 526-538.

Konopacka A. 1998. Nowy dla Polskì gatunek kíelza, Dikerogammarus haemobaphes (Eichwald, 1841) (Crustacea, Amphipoda) oraz dwa inne rzadkie gatunki skorupiakow obunogich w Wisle. Prz. Zool., 42: 211-218.

Konopacka A, Jazdzewski K. 2002. Obesogammarus crassus (G.O. Sars, 1894) - one more Ponto-Caspian gammarid species in Polish waters. Fragmenta Faunistica. 45: 19-26.

Martynov LW. 1924. K poznaniju reliktovykh rakoobraznykh bassejna Nizhnogo Dona, ikh etologii i rasprostranenija. Ezhegodn. Zool, muz. Akad, nauk. 25: 1-115.

Mordukhaj-Boltovskoj FD. 1964, Caspian Fauna beyond the Caspian Sea. Int. Revue ges. Hydrobiol. 49: 139-176.

Mordukhaj-Boltovskoj FD. 1979. Biogeography of the Volga. In: Mordukhaj-Boltovskoj FD, ed. The River Volga and its life. Monogr. Biol., 33: 346-366.

Mordukhaj-Boltovskoj FD, Dzjuban NA. 1976. Izmenenija v sostave i raspredelenii fauny Volgi v rezultate antropogennykh vozdejstvii. In: Biologicheskie produkcionnye processy v bassejne Volgi. Inst. Biol. Vnutr. Vod, Akad. Nauk SSSR, "Nauka", Leningrad: 67-82.

Mordukhaj-Boltovskoj FD, Greze II, Vasilenko SV. 1969. Otriad amfípody ili raznonogie-Amphipoda Latreille, 18161817. In: Kísíeleva MI, Mordukhaj-Boltovskoj FD, Murina WW, eds. Opredelitiel' fauny Chernogo i Azovskogo morej, Kiev: 440-524.

Müller O, Zettler ML, Gruszka P. (2001). Verbreitung und Status von Dikerogammarus villosus Sovinsky (Crustacea: Amphipoda) in der mittleren und unteren Strom-Oder und den angrenzenden Wasserstrassen. Lauterbornia $41 \times 105-112$.

Pinkster S, Scheepmaker M, Platvoet D, Broodbaker N. 1992. Drastic changes in the amphipod fauna (Crustacea) of Dutch inland waters during the last 25 years. Bijdr. Dierk. 61: 193204.

Rudolph K. 2000. Gebietsfremde malakostrake Krebse in mittleren Teil Brandenburgs. Aktueller Stand der Verbreitung. Neozoen 3: 10-11.

Sars GO. 1894-1895. Crustacea caspia. Amphipoda. Bull. Acad. imp. Sci. St.-Petersbourg, vol. 1(2): 179-223; vol. 1(4): 343378; vol. 3(3): 275-314.

Segerstrale SG. 1954. The Freshwater Amphipoda, Gammarus pulex (L.) and Gammarus lacustris G.O. Sars, in Denmark and Fennoscandia - a Contribution to the Late- and PostGlacial Immigration History of the Aquatic Fauna of Northern Europe. Comment. biol., Soc. Sci. Fenn. 15: 1-91.

Stebbing TTR. 1906. Amphipoda, 1. Gammaridea. Das Tierreich 21: $806 \mathrm{pp}$.

Stock JH. 1968. A revision of the European species of the Echinogammarus pungens--group (Crustacea, Amphipoda). Beaufortia 16: 13-78.

Stock JH. 1974. The systematics of certain Ponto-Caspian Gammaridae (Crustacea, Amphîpoda). - Mitt. Hamburg. Zool. Mus. Inst. 70: 75-95.

Szymanska H. 1990. Wplyw slonych wod z kopaln wegla kamiennego na jakose wod Odry. Gospodarka Wodna 5: 116121.

Tittizer T. 1996. Vorkommen und Ausbreitung aquatischer Neozoen (Makrozoobenthos) in den Bundeswasserstrassen. In: Gebhardt $\mathbf{H}$, Kinzelbach $\mathbf{R}$, Schmidt-Fischer $\mathbf{S}$, eds. Gebietsfremde Tierarten. Auswirkungen auf einheimischen Arten, Lebensgemeinschaflen und Biotope. Situationsanalyse. Umweltministerium Baden Wurttemberg, Ecomed Verlagsgesellschaft: 49-86.

Tittizer T, Leuchs H, Banning M. 1994. Das Makrozoobenthos der Donau im Abschnitt Kelheim - Jochenstein (Donau km 2414 - 2202). Limnologie aktuel 2: 173-188.

Tittizer T, Schöll F, Banning $\mathbf{M}$, Haybach A, Schleuter $\mathbf{M}$. 2000. Aquatische Neozoen im Makrozoobenthos der Bìnnenwasserstraßen Deutschlands, Lauterbornia 39: 1-72.

Van der Velde G, Rajagopal S, Musko I, Bij de Vaate A. 2000. Ecological impact of crustacean invaders. General considerations and examples from the Rhine River. In: von Vaupel Klein JC, Schram FR, eds. The biodiversity crisis and Crustacea. Proc, $4^{\text {th }}$ Intern. Crustacean Congress, vol, 2, Brill, Leiden. Crustacean Issues 12: 3-33.

Wawrzyniak-Wydrowska B, Gruszka P. 2001. Gammarus tigrinus and Pontogammarus robustoides - new gammarid species in the river Odra/Oder estuary. Abstr. III Int. Symp.x Functionning of Coastal Ecosystems in Various Geographical Regions, Gdynía, June 19-22, 2001 : p. 29.

Witt JDS, Herbert PDN, Morton WB. 1997. Echinogammarus ischnus: another crustacean invader in the Laurentian Great Lakes basin. Can. J. Fish. Aquat. Sci. 54: 264-268.

Zettler ML. 1998. Zur Verbreitung der Malacostraca (Crustacea) in den Bínnen- und Küstengewässer von MecklenburgVorpommern. Lauterbornia 32: 49-65.

Zmudzinski L. 1957. Zoobentos Zalewu Wislanego. Pr. Morsk. Inst. Ryb. 9: 453-500.

Received: 12 February 2002 